\title{
4.3 Основні аспекти управління економічною безпекою на різних ісрархічних рівнях
}

При розгляді економічної безпеки кожне явище має вивчатися як певна система складових його елементів, як єдність взаємопов'язаних і взаємодіючих предметів, процесів, відносин. 3 позиції забезпечення економічної безпеки під цілим Ярочкин B.I [114] розуміє систему такого типу: «Суб’єкт - Об’єкт Система безпеки безпеки» для будь-яких об’єктів, рівнів і масштабів.

Економічній безпеці на різних ієрархічних рівнях притаманний інтегральний характер. Співвідношення частини i цілого вивчаються загальнонауковими методами аналізу та синтезу, що $\epsilon$ протилежно спрямованими й разом 3 тим нерозривно пов'язаними способами пізнання. 3 тим або іншим ступенем конкретизації ці об’єкти підлягають захисту в економічній системі кожного інституціонального рівня. Об'єкти економічної безпеки розглядаються в інституціональному і функціональному аспектах [114].

Згідно з українським законодавством «поняття «національна безпека» зумовлює таку державну політику у цій сфері, яка має враховувати поточний стан і перспективи розвитку внутрішніх та зовнішніх чинників» [115, с. 42]. Зокрема Власюк О.С., досліджуючи національну безпеку України виділяє іiі базові принципи - комплексності та системності. Вони покладені в основу політики національної безпеки США (Закон про національну безпеку, 1947 р.) та на них базується й концепція національної безпеки України [115, с. 43]. При цьому комплексність державної стратегічної політики полягає у спільній участі не тільки представників різних гілок влади, господарсько-керівної та політичної еліт, але наряду з іншим й наукової спільноти.

Доцільним є розгляд державної політики національної безпеки на стратегічному рівні з використанням загальних підходів та методів задля уникнення зосередження уваги лише на іiї складниках та тактичних цілях, що можуть не на всіх рівнях збігатися із загальнонаціональними. «Дотримання 
принципу системності державної політики забезпечуватиме найвищу пї ефективність, гармонійне та взаємопов’язане функціонування іiі складників» [115, с. 42]. У результаті використання принципу системності збережеться загальна ефективність державної політики [115, с. 42].

Проте на законодавчому рівні, згідно зі ст. 2 та ст. 25 Закону України «Про національну безпеку України» [116], незважаючи на те, що економічна безпека є складовою національної безпеки, принципи розглянуто більшою мірою відносно її воєнної та політичної складових.

До основних принципів економічної безпеки доцільно віднести принципи, які грунтовно розкривають Ярочкин В.I. [114], Верхоглядова Н.I. та Олініченко І.В. [117], Шуршин В.О. [119].

1. Принцип системності. Він є основоположним принципом економічної безпеки. В його основі знаходиться співвідношення цілого (не є тотожним сумі частин, воно володіє новою якістю, відсутньою в частинах i виникає у результаті їх взаємодіiі) і частини (має відносну самостійність, властивими ій якісними особливостями і може, в свою чергу, розглядатися як ціле зі своїми складовими частинами, але вже меншого масштабу). За цим принципом здійснюється побудова економічної безпеки за ієрархічними рівнями. Будь-яке явище в сфері економічної безпеки доцільно вивчають як ціле, відносно самостійне, що включає ряд явищ меншого масштабу, воно є частиною більшого явища, відбиває його вплив на ціле та на нього впливає. За цього принципу, як розкрито в праці [117], відбувається облік внутрішніх взаємозв’язків і взаємозалежностей та зовнішніх чинників з позицій розгляду об’ єкту дослідження як елементу економічного простору більш високого рівня.

2. Принцип взаємозв'язку і взаємозалежності. Його сутність полягає в тому, що усі елементи системи нерозривно пов'язані між собою і одночасно впливають один на одного всередині системи.

3. Принцип визначальних чинників, його сутність полягає у виділенні істотних зв'язків та відносин, що мають вирішальний вплив на стан безпеки. Цей принцип дозволяє відсіяти другорядні чинники впливу, що не справляють 
значний вплив на функціонування економічної безпеки.

4. Комплексності. Він полягає у необхідності аналізу усіх сторін об'єкту дослідження (галузевої і територіальної, соціальною, технічної і екологічної складових).

5. Принцип варіантності (альтернативності). Сутність цього принципу полягає у виявленні та обгрунтованості кількох варіантів виходу з кризової ситуації, з одного боку та розрахунку траєкторії соціально-економічного розвитку на майбутнє, з іншого.

6. Принцип безумовного пріоритету економічної безпеки як найважливішого елементу якості життя i соціального прогресу, тобто пріоритетності рішення завдань i здійснення заходів, спрямованих на збереження здоров'я і життя людини, підтримку нормальних умов його існування.

7. Принцип прийнятного ризику, тобто виявлення і реалізації доступних заходів, спрямованих на захист людини в ринковому середовищі і недопущення кризових ситуацій.

8. Принцип сумісності технічної і соціальної складових економічної безпеки і безумовного пріоритету останньої.

9. Принцип компромісу між поколіннями з акцентом тяжкості подолання кризових ситуацій сьогодні.

Зокрема, на макрорівні Користін О.С., Барановський О.І. та Герасименко Л.В. [118], виділяють принципи забезпечення економічної безпеки держави [118], що, на відміну від принципів, визначених в Законі України «Про національну безпеку України» [116], незважаючи на схожість за змістом їх окремих положень, об'єднують макрорівень 3 мезо-, мікро- та рівнем сім'ї, особи, інакше кажучи дослідження економічної безпеки відбувається через призму національної безпеки. До таких принципів відносять:

- верховенства закону під час забезпечення економічної безпеки;

- додержання балансу економічних інтересів особи, сім’ї, суспільства, держави; 
- взаємної відповідальності особи, сім'ї, суспільства, держави щодо забезпечення економічної безпеки;

- своєчасності і адекватності заходів, пов'язаних із відверненням загроз і захистом національних економічних інтересів;

- пріоритетності договірних (мирних) заходів у вирішенні як внутрішніх, так і зовнішніх конфліктів економічного характеру;

- інтеграції національної економічної безпеки 3 міжнародною економічною безпекою.

Принципи економічної безпеки на мезорівні (рівні регіону) поділяються на загальні - комплексності, системності, варіантності (альтернативності), прийнятного ризику (Користін О.С., Барановський О.I. та Герасименко Л.В. [118], Шуршин В.О. [119], що можуть бути віднесені за своєю сутністю до основних та спеціальні - економії ресурсів, циркуляції інформації, балансу інтересів, «екватору» (Верхоглядова Н.І. та Олініченко І.В. [117]) - до підрядних. Ці принципи, як зазначено в працях [118-119] $є$ основою формування системи економічної безпеки регіону, оцінки ії загроз та їх наслідків.

До основних принципів функціонування систем Шнипко О.С. [120] відносить:

- принцип ефективного цілеформування (полягає у тому, що ціль ефективної поведінки системи задається над системою);

- принцип цілісності (стверджує, що ціле є більшим від суми складання його елементів, тобто система має властивості, які не виводяться із властивостей її елементів та способів їх поєднання);

- принцип детермінізму (його сутність полягає в тому, що причина зміни стану системи завжди знаходиться поза системою);

- принцип оптимальності (стверджує, що система повинна рухатися до мети за оптимальною траєкторією);

- принцип спеціалізації і кооперування (полягає в тому, що рухаючись до мети, система має тенденцію спеціалізуватись на виконанні своєї функції та 
кооперуватися з іншими системами);

- принцип ієрархічності (стверджує, що розвиток системи здійснюється ієрархічно).

Доцільно окремо виділити основні принципи забезпечення економічної безпеки регіону, до яких Користін О.С., Барановський О.І. та Герасименко Л.В. [118], Шуршин В.О. [119] відносять: принцип інтеграції з національною економічною безпекою; додержання балансу регіональних інтересів; чітке розмежування змісту діяльності, повноважень та відповідальності органів державної влади на державному та регіональному рівнях; чітке розмежування повноважень і відповідальності органів державної влади та місцевого самоврядування; прагнення до примноження національного багатства країни шляхом ефективного використання природно-ресурсного, науково-технічного, фінансового, інтелектуального трудового потенціалу регіону.

Також існує класифікація принципів організації та здійснення захисту у сфері економічної безпеки регіону (Головня Ю.І. [121]):

1. Системності. Передбачає розгляд проблем захисту з урахуванням усіх небезпечних каналів відпливу інформації та несанкціонованого доступу до неї, а також можливого часу та умов їх виникнення, комплексного застосування правових, організаційних та технічних заходів щодо захисту; при цьому має бути забезпечена спадкоємність та безперервність захисту.

2. Обгрунтованості. Оскільки складність завдань, що вирішуються, великий обсяг робіт, а також обмеженість ресурсів зумовлюють необхідність глибокого науково-технічного обгрунтування рішень, що приймаються, всебічної оцінки щодо їх реалізації.

3. Достатності. Означає необхідність пошуку ефективних та надійних заходів захисту, без зайвих витрат i забезпечується використанням найдосконаліших методів та засобів захисту. За характером впливу на загрозу серед способів захисту можна виділити узгодження, стримування, протидію та примушення.

4. Гнучкості в управлінні. Забезпечує здатність, залежно від умов захисту 
та важливості об’єктів, що захищаються, прогнозування загроз та запобігання їх нейтралізації, оперативну та ефективну ліквідацію наслідків цих загроз;

5. Своєчасності. Зумовлюється необхідністю завчасної розробки заходів захисту та контролю (у протилежному разі проведення заходів щодо захисту може не лише не дати ефекту, а й призвести до додаткових збитків).

У загальному вигляді на мікрорівні до принципів економічної безпеки Користін О.С., Барановський О.І. та Герасименко Л.В. [118] відносять: комплексність (системність); пріоритет заходів попередження; безперервність; законність; плановість; економність; взаємодія; компетентність; поєднання гласності та конфіденційності.

На мікрорівні зважаючи на предметну сферу дослідження здійснено поділ за групами на загальні та спеціальні принципи забезпечення економічної безпеки підприємства. Принципи комплексності, системності; безперервності [114, с. 5], обгрунтованості, достатності, гнучкості, своєчасності [122] за своєю сутністю є загальними, їх також можна віднести до основних. Принципи пріоритету заходів попередження; законності; плановості; економності; взаємодії; компетентності; поєднання гласності та конфіденційності; гнучкості; активності; законності; економічності; спеціалізації; взаємодії і координації; удосконалення; централізації управління [114, с. 5, с. 9] являються підрядними за змістом й можуть бути віднесені до спеціальних.

Зважаючи на сутність принципів та їх роль і значення задля забезпечення економічної безпеки та управління нею (вони є одночасно зведенням основних законів управління та правилами управлінської діяльності [123, с. 33, 124, с. 150]) на основі узагальнення наукових напрацювань у сфері управління економічною безпекою на макро-, мезо- та мікрорівні здійснено виокремлення принципів [125-129]. При цьому, окремо Ляшенко О.М. в праці [124, с. 149] виділяє принципи управління економічною безпекою підприємства, що виступають в якості правил, на основі яких здійснюється функціонування організацій, визначають поведінку суб'єкта й об’єкта в процесі управління та характер взаємовідносини організації 3 навколишнім середовищем. Вони 
відображають закономірності розвитку управлінських відносин, внаслідок чого $\epsilon$ логічним завершенням ланцюжка: «закони - закономірності - досвід управління - принципи» [124, с. 149].

Враховуючи вищенаведене слід зазначити, що реалізація на практиці виокремлених й систематизованих принципів управління економічною безпекою на різних ієрархічних рівнях дозволить приймати адекватні управлінські рішення в сучасних умовах господарювання з урахуванням ризику та невизначеності задля нівелювання чи принаймні зменшення негативного впливу загроз економічній безпеці. 